\title{
Co-being, A Praxis of the Public: Lessons from Hindu Devotional (Bhakti) Narrative, Arendt, and Gandhi
}

\author{
Leela Prasad ${ }^{*}$
}

Most controversies about religious representation enact conceptions of the public that construct boundaries which stridently mark insiders and outsiders, friends and foes, or practice and theory. This article begins with a controversy in California over representations of Hinduism in middle-school textbooks. A legal settlement closed the controversy but brought little sense of closure. Asking more broadly why publics fail, I put together, through deliberate anachronism, elements of a praxis of the public taking from political philosopher Hannah Arendt and bhakti poets of the Hindu tradition from the sixth century to the sixteenth century. This alternative praxis of the public creates "co-being," a state of society achieved by reimagining how we occupy space, how we own things and ideas, and how we form pacts. Gandhi's ashram, in concept and practice, exemplifies how an unlikely commonality is a possible one and is in fact the foundation of a meaningful and sustainable public.

“THE MONKEY KING HANUMAN LOVED RAMA SO MUCH that it is said that he is present every time the Ramayana is told. So look aroundsee any monkeys?" In 2005, these two sentences about the popular Hindu epic tradition proposed to be included in a California middle school textbook

\footnotetext{
${ }^{\star}$ Leela Prasad, Department of Religious Studies, Duke University, Durham, NC 27708, USA. E-mail: leela@duke.edu. I am grateful to the anonymous reviewers of an earlier version of this essay for their astute feedback. Thanks also to Bruce B. Lawrence for his suggestions. To Ebrahim Moosa, my special thanks for his close reading of multiple drafts that helped me sift the grain from the sand.
}

Journal of the American Academy of Religion, June 2016, Vol. 0, No. 0, pp. 1-26 doi:10.1093/jaarel/lfw040

(C) The Author 2016. Published by Oxford University Press, on behalf of the American Academy of Religion. All rights reserved. For Permissions, please e-mail: journals.permissions@oup.com. 
triggered alarms in the Hindu American community. Outraged, two Hindu organizations protested to the California Board of Education. They asked that "monkey king" be deleted from the first sentence and the second sentence be removed. Going further, they proposed a number of other edits for various textbooks that included sections on early Indian history and modern Hinduism being considered for adoption in California schools. But the proposed edits started off a storm in a group of university-based scholars of Indian history and culture who argued that the edits countered historical fact. And so began a prolonged and pitched battle between the Hindu organizations on the one hand and the academic group on the other with unaffiliated members of the Indian American community and the Board caught in between.

The edits and counter-edits reveal a politics of representation and affiliation, each anchored in a discourse of "accuracy." For example, the Hindu groups recommended that the sentence describing early Indian society, "Men had many more rights than women" be changed to "Men had different duties (dharma) as well as rights than women. Many women were among the sages to whom the Vedas were revealed." The academic group objected, saying that the edit attempted to blot an unflattering aspect of early Hindu life. In the deliberations that ensued, the groups discredited each other on the basis of conflicts of interest. The faculty group pointed out that the Hindu American groups were affiliated to nationalist Hindu organizations in India that had a record of creating radically revisionist histories. In response, the Hindu groups argued that some of the protesting faculty were consultants to textbook publishers. After a contentious back-and-forth over many months, the board decided to include most of the edits suggested by the faculty, ignoring a majority of the edits proposed by the Hindu groups (CDE). ${ }^{1}$ Immediately members of the Hindu community filed lawsuits claiming that the consultation and approval process was rife with error and ruled by a bias toward judging Hinduism by the standard of Abrahamic traditions. The allegations and counter-allegations, and the tussle about terminology, tone, illustrations, captions, and "facts" went on until 2009 when litigation and courts settled the matter. ${ }^{2}$ But little sense of closure had been accomplished, and even

\footnotetext{
${ }^{1}$ See especially pages $93-126$ for the full list of edits and recommendations.

${ }^{2}$ In September 2006, the court ruled in the case filed by the Hindu Education Foundation that the textbooks complied with the legal content standards expected of textbooks containing religious or historical matter. However, the court also reprimanded the California Board of Education for not following regulations in the textbook approval process. A separate lawsuit filed by an organization called California Parents for the Equalization of Education materials was settled out of court in 2009, with the California Board of Education paying California Parents for the Equalization of Education $\$ 175,000$ to withdraw the lawsuit. My summation of the controversy draws from the full legal judgment (Concerned Historians 2009).
} 
less understanding was created between the groups. Thus, in November 2015, as California prepared again for another round of public input into sixth-to-tenth grade textbooks, the same groups were poised to collide on the same issues of representation, history, and cultural practice. A core change that the faculty group has recommended has drawn the ire of many Indian Americans: that the word "India" be replaced by "South Asia" Another group of faculty has circulated an online petition opposing that change, arguing it is both historically blindsided and culturally alienating; as of March 27, 2016, it had gathered over 20,000 signatures. The California board is scheduled to vote on the recommendations in May 2016 for textbooks that will be used in classrooms in 2017.

How a public is constituted, who adjudicates it, and what philosophical and ethical ends it seeks are central questions in the California textbook controversy. The dominant mood of the public sphere in cases like this is one of adversarial communication and debate, and often, of litigation. This mood returns us to the question of what "public" really means-or could mean. Michael Warner argues that the public sphere is a heterogeneous imaginary, quite unlike the Habermasian understanding of the public sphere as a space constituted by bourgeois intellectuals who through reason fashion and legitimize public opinion. Warner notes that the so-called public sphere in fact consists of several publics and also, critically, counterpublics that challenge dominant discourses. But what leaves us discontented is that, as Warner puts it, "Counterpublics are, by definition, formed by their conflict with the norms and contexts of their cultural environment, and this context of domination inevitably entails distortion. Mass publics and counterpublics, in other words, are both damaged forms of publicness..." (Warner 2005, 63, italics mine). Indeed, the various Hindu organizations, the unaffiliated parents' group, the academic cohort, and committees of the California Board of Education were a multitude of clashing and opaquely collaborating publics, publics that in the end did not succeed in arriving at a long-lasting consensus. Why not?

In exploring that question, I am more interested in the ethical transformation that is necessary to create a common public in which such multiple publics have overcome antagonisms. What leads to the failure of mutual understanding in a public? How can we generate and ensure public trust? More fundamentally, if there is a consciousness that characterizes a harmonious public, what concept and praxis of the public embodies that consciousness? In the sections that follow, I construct a dialogue between early South Indian Hindu traditions of sculpture and poetry and the twentieth-century insights of Mahatma Gandhi and the German Jewish philosopher Hannah Arendt to outline an alternative modality of envisaging the public sphere. I posit that there is little room for sustained solutions and visions unless conflicting publics create common ground by understanding and practicing what I call "co- 
being." Gandhi's envisioning of ashram life, cultivated through decades of experimentation, illustrates the concept and the practice of co-being.

\section{CO-BEING}

By co-being, I mean a praxis of the public, one that is built on the recognition that we share our worlds with others and with other forms of life. Yet, more importantly such sharing requires a transformation in our understanding of three categories: person, possession, and place. In cobeing, these categories become dialectical so that ultimately sovereignty is a collective good, not a private enterprise. This means that co-being is achieved by reimagining personhood in relation to how we occupy space, how we own things and ideas, and how we form pacts. The result of this transformation is a more capacious world where ownership is coconstructed and each of us is more assured. But co-being is not a state of utopian togetherness; on the contrary, the harmonious public with equal freedom for everyone becomes possible only when individuals and private collectives endure physical discomfort, risk, and uncertainty, as indeed do the protagonists of the narratives I present later in this essay.

This notion of co-being intersects with Hannah Arendt's conception of the public sphere, hereafter referred to as the public. For Arendt, the public is the "world." This world is the commonality that arises when we overcome "our privately owned place[s]" (Arendt 1998 [1958], 52), and therefore antagonistic or even multiple publics defeat the very idea (and idealism) of an Arendtian public. Private experiences, argues Arendt, need to "undergo an artistic transposition" so that they acquire a reality that is "seen and heard by everybody and has the widest possible publicity...the presence of others who see what we see and hear what we hear assures us of the reality of the world and ourselves" (Arendt 1998 [1958], 50). From the perspective of co-being, the resonant concept in Arendt's observation is assurance, although Arendt herself does not single it out or develop it. Our media headlines and the billboards in our cities proclaim that what is missing in our "dark times" of increasing estrangement is precisely assurance, the immense certainty that the world and we are with each other. This assurance is an ethical state, one I would argue that is realized not in a theological afterworld but in our immanent, embodied, and everyday lives. Without the condition of assurance, individuals become "imprisoned in the subjectivity of their own singular experience, which does not cease to be singular [even] if the same experience is multiplied innumerable times" (Arendt 1998 [1958], 57-58). Assurance, in its ethical sense, comes not through legal resolutions, but in our seeing what we each see and hearing what we each hear. 
The relevance of co-being as a praxis in order to repair a damaged public, to use Warner's term, applies not only to the California textbook controversy. Indeed all controversies are marked by divisiveness and some sense of (mis)representation resulting in the feeling that freedom has been apportioned in unequal measure. For instance, outrage over artistic work about religious subjects comes from the perception that the artist has assumed the freedom to trespass on what is held sacred by others. The 1987 photograph of "Piss Christ" by the artist Andres Serrano, in which a small plastic crucifix of Christ is shown immersed in Serrano's urine, brought him both funding from the National Endowment of the Arts and hate mail and the vandalization of galleries that displayed his art. Serrano claimed that his intention was to "disturb" the viewer rather than to offend the religious sentiment of Christians. Piss, blood, and semen, Serrano said, were aesthetic materials in the same way that homeless persons were for his portraits (1997). While he argued that the symbolic range of this aesthetic material helps him evoke meaning, Catholics in Australia and the United States saw it as desecration. Similarly, the cartoons lampooning the Prophet Muhammad-in the 2005 Danish Jyllands Postein, the 2014 French Charlie Hebdo, and the 2015 art contest held by the American Freedom Defense Initiative, for instance-are justified by sponsors on the ground that art is its own empire. Who owns the right to images or right to imaging, and what freedoms clash with this assumption of ownership in this empire and outside its borders?

In the California textbook case, the edits, like serrated truths, were the outward projections of beliefs such as "This isn't the historical record," "This is not who we are," or "This is not what our children should be seen to be." The content of freedom revolves around such invisible motivations that are tested deeply by contestations over fact, diction, and image in ways that content review panels can hardly address, no matter how much they sharpen their tools. The exchange over edits anchors broader questions that the settlement did not answer but which are necessary for co-being. For instance, does the desire for historical accuracy completely free us from being sensitive to the lived experiences of a community being represented? On the other hand, does awareness of a community's representational dilemmas-even its very fiction of community, for examplegive us the freedom to doctor knowledge? What we learn is that colliding publics do not produce what we may progressively call an environment of "reflexive critique" or "democratic debate" but in fact engender victimization, polemic, and violence. We come face to face with a definition of freedom that promotes its flourishing at the expense of the blatant disregard of the freedom of another. It is only dialogue between equals (samva da in Sanskrit) that can ensure freedom for all, and I argue, such an equal freedom is experienced through co-being. 
The limitation of imagining the public sphere as a secular space that is avowedly nonreligious is that all encounters with the ineffable, staggering in their pervasiveness, their diversity, and their persuasion, are dismissed usually as irrelevant fables, or, in postsecular language, as fables that can become relevant to a democratic public only when they have been translated into a universal idiom and speak "with reason"-as Jurgen Habermas insists (2011, 25-28). Who determines the adequacy of such a translation? And-leaving aside the problem of Habermas's binaries of religious or secular citizenship-should it be only the "religious citizen," and not the secular, who must accept the "proviso" (Habermas's term) to translate her or his view into universal language? The proviso, it seems to me, is more fruitfully replaced by a dialogic. To begin with, as Habermas asks, the secular citizen would be required to not dismiss religious contributions to political opinion as "mere noise, or even nonsense" $(2011,26)$. But beyond that, the dialogic would also require that the secular citizen imaginatively enter the world of the religious citizen and understand it in its own terms rather than in a translated universal. ${ }^{3}$ To illustrate, in a yoga class I attended at my university in the United States, the instructor prefaced the class by saying, "I will say the word 'namaste' and ask you to bring your hands together. Please do not think namaste is some religious incantation. It is just a form of greeting." She had indeed translated namaste into a universal idiom, expelling from it all religious sentiment to make it available for those unfamiliar with Hindu or even Indian culture. Yet, well-meaning as this translation is, we can only wonder about the difference in experience if participants stepped into the Hindu world of "namaste" (humility or prayer, for instance) imaginatively for the duration of the gesture without feeling their personal sanctity was at stake. Yet, the dialogic can only occur when Hindu practitioners on their part let go of their custodial hold over religious symbols and practices like "namaste" or "yoga." (Defamation becomes an opportunity for "the offended" to respond not with violence but with vigor, a vigor directed at reinforcing the principles that uphold a shared world.) The stories from Hindu bhakti traditions that I now turn to are located in the ordinary materiality of everyday life. Rather than being just fables of faith in need of an irreligious translation, I suggest that they be seen as enacting, through their religious

\footnotetext{
${ }^{3}$ Habermas's call to the religious citizen to translate religious insights into universal ("secular") language may seem to resemble Arendt's call for "artistic transposition" of the private. However it is important to note that the private Arendt means includes secular and religious selves, making Arendt's "transposition" more egalitarian than Habermas's "translation" which is something enjoined only upon the religious citizen.
} 
worlds, the ethics of accommodation, nonpossession, and assurance, without which there can be neither a secularist politics nor a pluralist society.

\section{HOW WE OCCUPY SPACE: CO-BEING THROUGH ACCOMMODATION}

A key element that shapes the praxis of co-being is how we occupy space. The Divyasüricarita, a hagiographical text composed by the poet Garuḍavāhana (twelfth to thirteenth centuries), narrates an originating moment of the Âlvār Srivaișnava tradition from the sixth century. In one variant of the story, the first three saints of this tradition, Poykai, Putat, and Pey, paradigmatic devotees of the god Vishnu, live in their own separate hometowns in the Tamil country, unknown to each other. ${ }^{5}$ They each set out in search of Vishnu and their separate journeys bring them at night to a small town called Kovalur on the banks of the river Pennai. A torrential rain overtakes the dark night. Poykai finds an abandoned hermitage and takes shelter on a covered platform running along the outside wall of the hermitage. The platform (dehali in Sanskrit) is narrow but he can lie down comfortably. Soon, Putat, also caught in the downpour, discovers the same shelter. To accommodate him, Poykai makes space, but it is necessary for the two to sit in order to fit on the platform. When Pey, the third poet arrives, however, they are all obliged to make room for each other, which they can only do by standing. As they spend the night talking in the cold, cramped, and dark space where they cannot see each other, they begin to feel a fourth invisible presence squeezing into their midst, somebody who had entered the space from neither inside the hermitage nor from outside. Who was it?

In a flash, the three poet-saints simultaneously realize that it is the god Vishnu who has joined them. Each poet "sees" him, ${ }^{6}$ and astonished, bursts into a verse that describes the extraordinary form that he has seen. The darkness in the dehali is dispelled. These first verses (of the one hundred attributed to each saint) were born out of the epiphanic dehali

\footnotetext{
${ }^{4}$ Between the sixth and tenth centuries CE, twelve poet-saints (the Ālvärs, or the immersed ones) visited various Vishnu shrines in South India, mapping a "divya deśam" (sacred country). They expressed their visionary experiences in poems, which, like the Vedas, came to be regarded as divine revelation by a new community of Vishnu adherents called Srivaishnavas that consolidated in the eleventh century CE. The tradition's first teacher, Nathamuni (tenth century CE), compiled these poetic compositions into a collection called Nātayyira Divya Prabandham (The Divine Collection of Four Thousand Verses). Âlvār songs became part of daily liturgy, and are sung regularly in Srivaishnava homes and temples (Narayanan 1987).

${ }^{5}$ I summarize the narrative from Cutler $(1987,122-30)$ and Hardy $(1979,277-325)$.

${ }^{6}$ The allusions and the iconography belong to well-established Vaișnava worship.
} 
experience and initiated the great poetic legacy of the Âlvār tradition of South India. ${ }^{7}$

Poykai sings:

With earth as the lamp

and the sweeping oceans as the ghee,

and the sun with its fiery rays

as the flame,

I have woven a garland of words

for the feet of the Lord,

who bears a red flaming wheel,

so I can cross the ocean of grief. (Narayanan 2007, 191)

Putat is intensely moved:

With love as the lamp,

ardor as the fuel,

thoughts that drip passion

as the wick,

With melting heart,

I lit the blazing flame of wisdom

for Narana [Narayana/Vishnu]. (Narayanan 2007, 204)

And Pey exclaims:

I saw Tiru

I saw his body of gold,

I saw his glorious hue, bright as the sun,

I saw his golden wheel, triumphant in battle

And the spiral conch he holds in his hand -

Today I saw all these signs of my lord,

Whose body is blue as the sea. (Cutler 1987, 128)

Brought together by journeys in search of something, the three poets discover the presence of a remarkable "other" because they spontaneously share a limited space: one can lie down, two can sit, and three can stand. I see these seemingly unremarkable acts of accommodation, of hospitality, in the narrow dark dehali as foundational to the idea of co-being. The physical discomfort the poets endure engenders a metaphysical awareness that transforms an enigmatic other into a deeply familiar presence. Co-

\footnotetext{
${ }^{7}$ These verses are called the Tiruvantäti(s) and are sung and performed in liturgy by Srivaishnavas all over the world today. Studies of the compositions of the twelve Âlvār saints elaborate on their defining influence on South Indian bhakti (devotionalism), on the metaphysics of the Vedāntic school of Vișișthadvaita (qualified nondualism), and on Tamil literary traditions (Venkatesan 2011).
} 
being then is grounded in the acceptance that comfort zones will be altered, but collective enjoyment and edification stand to be gained through this sacrifice. The absence of proprietorship over a space, or original claim on it, yields insights into what is possibly the "same" thing, and an exciting new generation of knowledge expresses itself in a new religious tradition. This affective and aesthetic pluralization, rooted in how we occupy space, can be imagined as central to the ethos of the "world." It is similar to the one that Arendt envisaged and as I will later show, Gandhi implemented. Pluralization also means that each poet differently interprets the presence they jointly experienced. The poet expresses himself through a visual vocabulary that is specific to Vishnu and to the Tamil language. But the poet transcends particularity by using metaphors of primal elements (earth, water, fire) and primary human emotions (love, passion, need for protection). This metaphoric "transcendence" makes Vishnu visible to a wider community, through the act of creating a community. As Arendt hoped, a true public is generated only when the private self is able to undergo artistic transposition.

But let us return to Alvars' experience of discomfort in the crowded passageway. Can the acceptance of discomfort be a prerequisite to resolving fraught spatialities, a central provocation in human history? Addressing the conflict between Israel and Palestine, Judith Butler explores the moral potential of the term "cohabitation." She writes, "Since there is no home without adjacency, and no way to reside anywhere without the outside defining the space of inhabitation, the co of cohabitation cannot be thought simply as spatial neighborliness...So the question emerges: what obligations are to be derived from this dependency, contiguity, and proximity that now defines each population which, as we know, sometimes incites destructiveness? How are we to understand such bonds, without which neither population can live and survive? To what postnational obligations do they lead?" (Butler 2011, 89). A political answer to these questions not only needs to terminate violence, Butler argues, but also needs to work through an ethics of remembrance. That is, in her example, "Jewishness" (drawing on Arendt) needs to mean not just a religious-cultural identity. More urgently, the memory of the Jewish experience of displacement and trauma needs to translate into a commitment of "never again" to the dispossession of any people. While cohabitation depends on the creation of empathy through remembrance, Ajay Skaria draws our attention to a more fundamental force in which neighborliness is not the byproduct of accidental adjacency. Instead, neighborliness in the Gandhian sense requires that "neighbors shared nothing less (or more) than the kinship of all life; beyond this, the 
neighbor was marked by an absolute difference that could not be overcome by shared history or culture" (Skaria 2002, 957).

Even remembrance, the songbird of history, does not invariably serve co-being. Ashis Nandy provides a deeper insight. An effort to accommodate others, he points out, sometimes requires us to undergo the discomfort of having to forget. Reflecting on the stories of people who had witnessed the murders of their kin by friends and neighbors during the brutal partition of the Indian subcontinent, Nandy observes, calls for one to carry on once again with life and similar neighbors in a mode of a "principled forgetfulness" (Nandy 1995, 47, 66). Such are the discomforts of co-being these individuals need to develop. Principled forgetfulness is, Nandy elaborates, "... what you should forget on ethical grounds, even though you know you cannot forget. The unforgettable that you still must make an effort to forget, an effort to forget, because it is only principled forgetfulness which can liberate you from the past" (Nandy 2009). In sum, accommodation as a necessary aspect of co-being is a particular moral imagination of space as world to be constructed through selfconscious practices. Interspace, a less-cited word in Arendt's lexicon, is relevant here. It refers to the space between people, a space that both separates and also connects them. In fact, the world as Arendt meant it, "can form only in the interspaces between [people] in all their variety," and so crucial did she imagine the interspace to be that she said if we were to lose it, we would lose the world itself (Arendt 1968, 13, 31). Characterized by distinctness and equality (based on kinship), the interspace is created through accommodation. ${ }^{8}$

\section{HOW WE OWN THINGS: CO-BEING THROUGH NONPOSSESSION}

About 350 kilometers sharply south of the metropolis of Chennai, in a town called Ettukudi, is a temple with its shrine to the peacock-riding god Velan. In most South Indian Hindu traditions, Velan is the son of Siva and the brother of the popular elephant-headed god, Ganeśa. The threefaced, twelve-armed image of Velan is seated on an intricately carved peacock that looks toward his left. The entire weight of the statue is borne by the legs of the peacock. ${ }^{9}$ A fascinating variant of the story of this temple's origin is recounted in the award-winning documentary film called Vastu Mārabu: The Living Tradition, A Shilpi Speaks by Bala Kailasam (1990).

\footnotetext{
${ }^{8}$ See Prasad 2015 for how the idea of interspace works as a textual strategy in comparative reading.

${ }^{9}$ See http://www.ettukudimurugan.com.
} 
The story is that a fourteenth-century Tamil king called Muttarasan commissions his court sculptor to make an image of Velan seated on his peacock. As the image nears completion, the king has a strange dream in which he sees the sculptor engrossed in sculpting the peacock, when all of a sudden, the peacock takes flight, carrying Velan along with him. As onlookers exclaim "Ettipidi, ettipidi" (Catch it! Catch it!) the startled sculptor throws his chisel at the flying peacock. The chisel hits the bird's claw and the injured bird returns to the ground. On waking, the king goes to the sculptor's yard and is amazed to see that the claw of the peacock image is dented. He relates the dream to the sculptor. The sculptor puts his tools away, concluding, "Velan has arrived." This dented sculpture comes to be the sacred image of the famous Ettukudi temple.

A synoptic understanding of Hindu architecture and sacred imagery will help contextualize the questions I will ask of this story to illustrate cobeing. Hindu architectural texts very carefully specify the rules, roles, and rituals that are involved in the production of sacred material forms. Although the stunning diversity and exuberance of temple architecture (whose history spans well over a thousand years) would seem to exceed the principles elaborated in these texts, the understanding remains fundamental. The temple symbolically connects the human to the divine and links the mundane to the extraordinary. Structured like the human body, the temple breathes embodiment. It is the material expression of an imagined cosmos that is ordered by vast imaginaries of time and space. Two other ideas are central to the Hindu temple: that it reflects the resources and the religious and political inclinations of a patron-elite, and that it is also the space of communal worship and public performance. Enhancing the symbolism of the temple are the literary and liturgical traditions that expand the meanings of its deities-their forms, their feelings, their powers, and their immutability. The intrigue and the invitation of the carefully crafted material image are continuously replenished by folklore, performance, and patronage. These performative acts make the deity accessible to devotional publics. Apart from the patron, three agents are usually identified as crucial to the image-/temple-making process: The head priest (sthapaka) who determines aspects of ritual auspiciousness; the chief architect (sthäpati) who conceptualizes space and proportion; and the sculptors (shilpi[s]) who render mythologies into artistic depictions (Bharne and Krusche 2012). Embedded in this complex finite and infinite world of the Hindu temple are questions that the Velan story draws out: Who owns the temple? Who owns the deity? Who has the knowledge to recognize when the material image has become Velan the deity? 
When the sculptor puts away his tools, he does so because the statue of Velan sitting on the peacock with the dented claw confirms the events in the King's dream. But it also signals that the enlivened sculpture is ready to leave the private space of the sculptor's yard in order to enter the public world of the temple. Indeed, in the dream, the community of onlookers knows that the peacock must be brought back: it carries none other than Velan who protects the public and anchors its identity. Implicit in the act of putting away the tools is the understanding that several authorities are interdependent in the making of an artifact for public ownership. That is, the King is a sovereign authority, commissioning and sanctioning the work of sculpture, and the sculptor has sovereign authority over the complex art of fusing "form" and "feeling." There is little ambiguity about roles and expertise; agency is not fuzzy but rather it is distributed. This distribution of authority makes the recognition of Velan's presence in the image a collaborative event: the King, who has the power and the duty of patronage, has the dream, and the sculptor has the knowledge and the experience to interpret that dream. The image moves along a continuum between dream-reality and everyday-reality, one corroborating the other, and this movement makes it both a body of art and the body of Velan, fashioning in the process an object of pleasure and a power that protects.

But this culmination takes place only because all actors recognize a limit: human finitude, which is a foundational precondition to co-being. Understanding the limitations of one's authority, knowledge, and experience shapes an ethics of humility. Co-being is governed by the following tacit principle: all knowledge is intrinsically collaborative and hence individual ownership of it is interim and jointly constructed. Even further, when the image is complete, it belongs neither to the sculptor, nor to the King nor even to the devotional public, but perhaps only to Velan-the one who is self-possessed and who possesses all. The greatest gain, the narrative suggests, occurs when ownership itself is relinquished in a grammar of nonpossession.

\section{HOW WE FORM PACTS: CO-BEING THROUGH ASSURANCE}

One of the busiest temple towns on the Hindu pilgrimage circuit is the town of Pandharpur in Maharashtra (western India) famous for its temple to Vithala, a regional manifestation of the deity Krishna. Also known as Pānduranga (shortened to Ranga), or Hari, the roughly fourfoot-high dark deity, imaged as a young boy, stands in the main shrine with his arms akimbo, inspiring many centuries of poetry and performance in Marathi and Kannada. Of interest to us is one song composed 
by the sixteenth-century poet-saint Purandara Dasa who is considered to have founded the South Indian music system known in modern times as Carnatic music. The song, which I translate below from Kannada, unquestionably fits into the broad aesthetic and ethical paradigm associated with Hindu bhakti (devotional) traditions. A pocketbook review of ten centuries of the development and efflorescence of bhakti will show that what began as a resurgence in the worship of Shiva and Vishnu between the seventh and thirteenth centuries in South India transformed Hindu theistic sensibility pan-regionally in permanent ways. Bhakti, in its essence, conceptualizes the deity as the devotee's most intimate friend or lover toward whom one expresses a range of emotions from ecstasy to anguish, anger to gratitude, longing to love. Full immersion in the divine and surrender to it are desired because the deity liberates one from the cycle of births and deaths. And, in this conceptualization, it is certain that the deity will, sooner or later, protect the devotee. The devotee imagines this refuge in the deity as the highest goal of human striving.

In this song, Purandara constructs a transactional relationship between himself and Ranga, proposing an exact give-and-take between them:

An oath [āne] on me, Ranga, and also on you

You and I are both bound by an oath on your devotees

To commit to no one else but you is my oath, Ranga

To not desert me is yours

To not be deluded by body, mind or wealth is my oath, Ranga

To still my mind in you is your oath to me

To be always among exemplars is my oath, Ranga

To keep me from the corrupt is yours

To stay away from the petty-minded is my oath, Ranga

To rid me of petty pursuits is yours

To seek refuge in you is my oath to you, Hari

O Purandara's Vithala, to not refuse me shelter is your oath to me

The imagination of ultimate sanctuary in the deity, characteristic of bhakti poetry, doubtless permeates Purandara's song, but the song delineates a dialectic of responsibilities that is necessary to move toward this sanctuary. The metaphor embodying this dialectic is ane, an oath, a pledge, a 
bond, and the program of oaths unfolds a lifeworld that is held together by reciprocity. In this lifeworld, the human is vulnerable, having to avoid everyday peril and to become an agent of self-growth. This agency of the private individual cannot be atomistic. Goodness is a collaborative accomplishment, while grace is left to divine will.

The moral force of the program of oaths is derived from its monologic imagination of a dialogue: Purandara spells out both sides of the pact and in doing so, completely trusts Ranga to live up to the pact. Interestingly, Ranga is contractually obliged by the devotee's trust to provide the overarching assurance of sanctuary that matches the assurances made by his devotee. Co-being, here, emerges from this ethos of assurance; that there are others "who see what we see and hear what we hear" affirming our humanity (Arendt 1998 [1958], 50). Without assurance, there can be no world, and no sanctuary. In terms of modern political times, we could ask whether a public that fails to provide assurance to its citizens can constitute a public at all. Can we still call it a public if it becomes instead, a scatter of fragmented publics, untrusting and at odds with each other, conferring at best a half-hearted citizenship to its equal others? Such a failure marked the California textbook case where many Hindus, despite being United States citizens, felt excluded by academics, and some underprivileged caste groups in America felt that the right-wing Hindu groups were silencing their historical experiences and on the whole, reinventing a convenient past.

Just as Purandara sees himself transformed into a "good person" through the enactment of a pact, so too we might say, an individual is transformed into a citizen not only by a legal process but also by the public's participation in a conjoined citizenship. Co-being implies that our policies and our actions have been inflected with moral pacts that recall human vulnerability, trust, and agency. "Grace" (described in the song as Ranga's responsibility) is no less the responsibility of a public, or the state, or any collective. As a praxis of the public, we might wonder whether cobeing is about how we can make states and publics that are not sponsors exerting patronage, but protectors guaranteeing assurance.

\section{GANDHI'S ASHRAMS: AN EXPERIMENT IN CO-BEING}

\section{Philosophical orientations}

There can hardly be a better advocate, or a better practitioner, of cobeing in the modern world than Mahatma Gandhi. It is hence poignant that Gandhi saw his own life as a struggle to resolve the pervasive dichotomy between self and the other, to dissolve the distinction between a 
private and a public self. What is really interesting about Gandhi's conception of the private-public continuum is that its ends are simultaneously socio-political and metaphysical. He writes, "What I want to achieve,-what I have been striving and pining to achieve these thirty years, - is self-realization, to see God face to face, to attain Moksha [Lit. freedom from birth and death. The nearest English equivalent is salvation]. I live and move and have my being in pursuit of this goal. All that I do by way of speaking and writing, and all my ventures in the political field, are directed to this same end" (1993, xxvi). In the closing lines of his autobiography, he muses, "But I know I have still before me a difficult path to traverse. I must reduce myself to zero. So long as a man does not of his own free will put himself last among his fellow creatures, there is no salvation [moksha] for him" (Gandhi 1993, 505) ${ }^{10}$ With the merging of the private and the public, only one single account that is visible to all is sufficient. Narration itself becomes unnecessary when the self is "zero." The Gandhian zero was not of the socially withdrawn religious ascetic; rather, it was of the selfless activist, immersed in public service. This zero was realizable through humility, which required a radical reconceptualization of the private in light of the well-being of the other, indeed, of the all. The daily drive and desire of the individual had to be scrutinized for its rightful place in life, and life in Gandhi's view is essentially societal, where "society" encompasses all forms of life. The only private that was beyond the public/private traffic of the mundane-secular world was an innermost self, distilled and inexpressible, "known only to oneself and one's Maker" (xxvii).

Gandhi saw religious diversity as a challenge to the creation and sustenance of common ground. The specific challenge was in constructing a practice that would go beyond a salutary acknowledgment of different approaches to transcendent realities and engage them through an ethos of equality. By the time Gandhi arrived at his own understanding of "God"-having spent fifty years in that search-he had reflected upon his Vaishnava upbringing and on other Hindu traditions. He had also explored in some depth the texts and practices of numerous non-Hindu religions. In a 1921 issue of the weekly Young India, he is emphatic that his own reason and feeling was the divining rod for accepting or rejecting religious propositions, not any external authority, however hallowed it was. The sacredness of Gandhi's "God" rested less on name and attribute and form (as his background might have led him to) but more on something

\footnotetext{
${ }^{10}$ Gandhi wrote his autobiography in Gujarati, completing volume 1 in 1927 and volume 2 in 1929. His close aide Mahadev Desai translated both volumes into English under Gandhi's supervision in 1940.
} 
inviolable and invariable: Truth. Thus he concluded, "Truth is God," an ontological understanding that both accommodated all conceptions and paths, including atheistic, and also made its own repudiation virtually impossible. In Gandhi's theology of Truth-whose votary he often called himself-the unwavering pursuit of Truth guaranteed an effulgent clarity in everyday routines and relations, but it also assured clarity in an immanent plane. "To find Truth completely," Gandhi writes, "is to realize oneself and one's destiny; i.e. to become perfect. .." (Gandhi 1921) and "... a perfect realization of Truth can only follow a perfect realization of Ahimsa" (Gandhi 1993, 504).

Ahimsa, as Gandhi intended it, went beyond its popularized understanding as nonviolence to mean nonharm to fellow-beings in intention, word, and act, together with love for all forms of life, achieved through imaginative identification. By reducing the self to zero through this identification, true ahimsa became the "farthest limit of humility" (Gandhi 1993, 505). And it was only the humility and humanity of ahimsa, in his view, that could effectively nullify the alienating relativism spawned by a multitude of competing truths-after all, "what may appear as Truth to one person will often appear as untruth to another person," admitted Gandhi $(1932,5)$. The adjudicating voice could only be the "Inner Voice," whose spirit is necessarily ahimsaic. Such a spirit has to be cultivated.

It is against this backdrop that Gandhi imagined the ashram as the physical habitation where individuals could comprehensively cultivate, through trial and error and dissent and dialogue, ahimsaic practices that embodied Truth. ${ }^{11}$ It is this sense that infuses Gandhi's economical definition of the ashram as a "community of men of religion" (Gandhi $1955,3) .{ }^{12}$ From the choice of the ashram's location to the construction of buildings and the rules of living-what one ate and wore, and how one worked, prayed, or interacted - the ashram was the material manifestation of the idea, the aspiration and the struggle for the ideals of co-being. To find the "kinship" [sagpan] that Skaria aptly identifies in the Gandhian context, ashram citizens, who came from all castes and all religions, were expected to embrace śrama, striving, which is the root of the Sanskrit word äsram (2002, 974). As Suzanne Rudolph and Lloyd Rudolph insightfully point out, unlike the Habermasian public sphere, Gandhi

\footnotetext{
${ }^{11}$ In Hindu traditions, an ashram refers to a particular kind of spiritual settlement, a retreat, dedicated to the observance of a lifestyle based on particular teachings. This lifestyle includes physical labor as well as spiritual work.

${ }^{12}$ Gandhi's use of the word "men" should not lead us to think that the ashram excluded women. In fact, he explicitly states, "Emancipation of women from some customary bonds was insisted upon from the first. Therefore women in the Ashram enjoy full freedom" $(1955,8)$.
} 
"created a public sphere among largely non-literate populations by amplifying the ashram as an exemplary community and by challenging racism, economic exploitation, and untouchability through satyagraha campaigns" (ahimsaic resistance based on the force of truth) $(2006,161)$.

Gandhi elaborates on the daily textures of this striving in a set of essays that he wrote when he was imprisoned in Yeravda Central Prison in Pune in 1932. Called Satyagraha Ashramno Itihas (The Story of the Satyagraha Ashram), ${ }^{13}$ this booklet was published in May 1948, four months after Gandhi's assassination, and translated from the original Gujarati into English in 1955 by V.G. Desai as Ashram Observances in Action. It is a retrospective account of how the concept and the practice of ashram life emerged from Gandhi's experiments with satyagraha in South Africa and India, and follows his earlier work, From Yeravda Mandir, which evolved from a series of letters he wrote while he was in Yeravda jail in $1930 .{ }^{14}$ Briefly, Gandhi's first attempt at co-living began at the 100acre Phoenix Settlement outside Durban in 1904, a settlement whose birth was inspired by John Ruskin's Unto This Last, first published in 1860. Three insights from Ruskin had a profound impact on Gandhi: First, the good of the individual is in the good of all; second, all occupations and professions have the same value and everybody has the same right of earning their livelihood from their work; and third, that the most revolutionary, the "life worth living" is a life of labor (Gandhi 1993, 299). The growth of the satyagraha movement in South Africa led Gandhi to set up, with backing from his close friend, the Jewish architect Henry Kallenbach, Tolstoy Farm in 1911 in the colonial Transvaal province of South Africa, today known as the Gauteng province. After he returned to India, Gandhi established two ashrams, calling them as such, Satyagraha Ashram, on the banks of the Sabarmati in Gujarat in 1915, and Sevagram Ashram, in the underdeveloped arid interior of Maharashtra in 1936. I will sidestep the unique histories of these two ashrams and consider instead a few experiences that Gandhi records in Ashram Observances in Action to illustrate the striving for co-being at these ashrams. ${ }^{15}$

\footnotetext{
${ }^{13}$ Tridip Suhrud points out that Gandhi did not like translating "itihās" ("it happened thus") to "history," which is the conventional translation of the term. History, for Gandhi, was the record of wars and conflicts and as such it would not be able to record instances of satyāgraha-soul-force as opposed to brute-force in the resolution of conflict (Suhrud 2011, 77).

${ }^{14}$ For a detailed account of the intellectual genealogy of Gandhi's idea of communal life and ascetic ideals, see Thompson (1993).

${ }^{15}$ There are several accounts of experiences in Gandhi's ashrams during his time. See, for example, Mehta 1993, Thompson 1993, Fischer 1942, and Guha 2004.
} 
There were eleven ashram vows. Constituted democratically, these aimed to translate the idealism of co-being into the nitty-gritty of everyday living. Five of the eleven vows echoed the moral principles (yama) of yogic practice (the practice of truth, ahimsa, celibacy, control of the palate, and non-stealing) and the other six evolved as a response to India's predicament at that time (swadeshi [indigenous production], fearlessness, removal of untouchability, education through the mother-tongue, handweaving, and political involvement). The vows displayed the warp and weft of an ahimsaic sensibility-they were exacting, suffused with otherconsideration, and intended to gradually make oneself and one's environment ecologically harmonious. The observance of ashram codes was voluntary; coercion or a sense of deprivation was seen as disabling the moral spirit behind them. ${ }^{16}$ "The ashram's publicness was realized by shedding the private commitments that made [residents] strangers to each other for shared commitments that made them an exemplary community" (Rudolph and Rudolph 2006, 161).

Many instances are recorded in Gandhi's ashram writings about the suspension of a vow in order to honor the truth the vow symbolized. For example, when an ashram resident wanted to marry, the ashram suspended the vow of celibacy and committed to helping the member find a partner. The resident, however, could not disavow the ashram's fundamental belief in the equality of all people and insist on the partner being of the same caste, subsect, and so on. ${ }^{17}$ Nor could he or she expect anything but the simplest symbolic ceremonial. An ahimsaic approach entailed compromise, but equality and simplicity set a limit to the compromise.

\section{Accommodation in the ashram}

The layout and the routines of the ashram put the individual and the collective in the discursive space of each other. The duties at the ashram, including physical labor, were distributed among residents and everyone was expected to perform every task, from gardening and the chopping of vegetables to spinning and the cleaning of latrines. Physically, the ashram interspaced individual huts-which expressed personal preferences and material innovations-and shared spaces such as the kitchen, library,

\footnotetext{
${ }^{16}$ The Gandhi who writes Ashram Observances is different from the Gandhi of his early South Africa days when he coerced Kasturba, his wife, into practices he advocated and practiced.

${ }^{17}$ By 1946, Gandhi, responding to caste-based polarizations that were rife in India, announced that if his presence at a marriage was desired, the marriage would have to be between a Harijan ("untouchable") and a "caste Hindu" (1932, 57 in a footnote by editor).
} 
latrines, vegetable farms, and prayer space, which conformed to the codes of collective living. The prayer space at Sevagram (which has been maintained as it was in Gandhi's time in the 1930s) epitomizes this flow between interiority and constructed openness. When I visited Sevagram in 2010, I saw a homely low bamboo fence suggesting the contours of the prayer space, a simple graveled quadrangle surrounded by low buildings and tall trees. At the regular early evening hour, residents and visitors sang songs and prayers from different religions and languages to the accompaniment of an ektara, the single-stringed instrument used in Indian folk music, performing a tradition that too has been retained since Gandhi's stay at Sevagram. "It was an Ashram rule," Gandhi had written, "that persons following a particular faith should have the same feeling for followers of other faiths as for their co-religionists" $(1955,8)$. Indeed, so powerful is this sense of religious accommodation that these prayer meetings have evoked a lasting resonance in those who have lived in Gandhi's ashrams either for long or short durations. As I reflect on the performance of religious plurality that takes place at Sevagram every evening, seeing it as a performative extension of the intentional diversity of ashram living, I am reminded of the insightful breakthrough into song experienced by the three Alvar saints of our earlier narrative from South India. And read through the collective evening prayer and the sharing of space, it seems to me that pluralization would seem to accomplish for co-being what limited editions of multiculturalism perhaps cannot: ethos-building through aesthetic transposition.

The more discomforting aspect of accommodation in the ashram, one that evoked resistance and curtailed membership to only those serious about ashram life, was the upkeep of latrines. At a time when scavenging human excreta was seen as a "low-caste" occupation, ashram residents cleaned public latrines and removed nightsoil, following a strict scientific procedure for this work. In From Yeravda Mandir, Gandhi says, "I have felt for years that there must be something radically wrong, where scavenging has been made the concern of a separate class in society.... We should, from our very childhood, have the idea impressed upon our minds that we are all scavengers, and the easiest way of doing this is, for everyone who has realised this to commence Bread labour [working to earn what you need] as a scavenger. Scavenging, thus intelligently taken up, will help one to a true appreciation of the equality of man" $(1932,54)$. As recorded elsewhere (Prasad 2007), in the eyes of Dodda Murthy, a now 95-year-old retired schoolteacher from Sringeri who visited Sevagram in 1942, indeed to clean well was not all. Dodda Murthy, an "upper-caste" boy, had been brought up to believe that latrine-cleaning was an abhorrent task. But in his twenty-one days at Sevagram, he realized that abhorrence was violent 
and not part of the ashram's perceptive or practical field. In the cleaning of latrines, he recognized a tacit orientation: first, one had to accept the idea that public toilets were cleaned by everybody—not a "special calling" but a "universal duty" (Gandhi 1955, 79); second, one had to learn how to clean them; third, one had to clean them well; and fourth, most importantly, one had to clean them without disgust. There was thus both a practicum and a phenomenology of co-being that he came to grasp as he overcame his repulsion and resentment as a visitor to becoming adept at, and appreciative of, the task. Latrine-cleaning became an act of ahimsa-leaving a public latrine unclean was not just a matter of plain inconvenience to others; it was a matter of causing them harm (himsa). Thus cleaning the latrines with love prevented harm.

\section{Ownership in the Ashram}

Gandhi recounts how a resident once caught a thief in the ashram. The resident had tied up the thief and humiliated him, infringing an ashram rule that punishment not be inflicted on thieves and police not be called in. When Gandhi discovered this, he rebuked the thief and set him free. Ahimsa requires, Gandhi says, the discovery of "methods that would put an end to thieving altogether" (Gandhi 1955, 46), an approach that redirected ashram residents to reflect on the material bases of citizenship. These methods called for both scrutinizing how much one owned and for developing "constructive programs" for the welfare and well-being of surrounding communities. The point: co-being must be founded on the distribution of the material things of life, for virtually everything is a product of an interrelated chain of making and consuming. By this approach, citizenship did not focus on the right to acquire property, but instead rested on the question of whether one's possessions exceeded one's needs. Excess, in the Gandhian analysis of ownership, was the seed of envy and desire that set the stage for thieving (Parekh 1989). Ahimsa is “...violated by holding on to what the world needs" but one does not oneself need (Gandhi 1955, 11). But to address thieving holistically, one needed to address deprivation in an advaitic sense (a unity of being that makes everything ethically accountable). A distant hunger is a hunger within. These hungers can all be satisfied by an ethic of nonpossessiveness, an ethic, to use Gandhi's terms, built not on proprietorship but on trusteeship. ${ }^{18} \mathrm{He}$ argues, "...I dare not possess anything which I do not need.... You and I have no right to anything more until these millions [of poor people] are clothed and fed better. You and I, who ought to

\footnotetext{
${ }^{18}$ For an exploration of trusteeship, see Weber (2011).
} 
know better, must adjust our wants, and even undergo voluntary starvation, in order that they may be fed and clothed" (Gandhi 1955, 137). Even a walk through the curated ashram at Sevagram today, where there is an embodied absence of clutter and expense, holds up the Gandhian response to inequity.

\section{Assurance of the Ashram}

In the very first month of the Satyagraha ashram, when it was still housed in a leased bungalow in Kochrab, a family's arrival laid bare hitherto unseen boundaries between insiders and outsiders at the ashram. Gandhi called it a turning point. The family of Dudabhai, his wife, Danibehn, and their young daughter, Lakshmi, who were not just visiting but were seeking to settle down at the ashram, belonged to a socalled untouchable caste. The initial welcome from the ashram's residents soon turned into subtle discriminatory behavior by some of them, including those who knew and voluntarily practiced ashram vows. Like many Hindus outside the ashram, the bungalow's keeper feared "pollution." He prohibited the ashram residents from using the well and he assaulted Dudabhai. External monetary support was also cut off. Gandhi contemplated moving to an "untouchable" neighborhood in the city rather than evict Dudabhai, but a generous donor suddenly offered support to the ashram. Even Gandhi's most trusted administrator and cofounder of the ashram, Maganlal, decided to leave with his wife for Madras (now Chennai) where they would learn weaving, a decision Gandhi felt was best because it would give them the distance and time they needed to reflect on the matter. Maganlal and his wife returned in six months.

One could analyze these happenings in terms of Gandhi's views on varna (caste) and untouchability. Or consider whether the episode is fraught with upper-caste patronage, as some of Gandhi's critics have claimed (Sarkar 2011). But let us stay with the everyday, the space in which Dudabhai and his family would have experienced the events at the ashram. It is in the everyday that we feel assured of the reality of our world and us. But the ashram's community could provide assurance only if members accepted each other as equals without the prejudice of predetermined social categories. "Untouchability," without a doubt, recorded the physical and emotional experience of discrimination and violence, but it did not constitute the entirety of Dudabhai's or Danibehn's personhood-their dreams, aspirations, needs, abilities and so on. The ashram would need to demonstrate to Dudabhai and his family, through its practices, that they had full fellowship in the ashram. 
Gandhi's unequivocal and undeterred inclusion of Dudabhai's family provided this very assurance that was essential for co-being in the ashram.

\section{CONCLUSION}

We can now return to the California textbook controversy of 2005 to ask how acts that characterize co-being could have made a difference to the outcome. To begin with, although we saw a semblance of accommodation as multiple parties negotiated editorial changes, the promise disappeared as the negotiation became focused on facticity versus lived experience rather than on dialogue, which was bound to be discomforting, about the challenges for interpretation presented by both "fact" and "experience." Ownership of knowledge and tradition became custodial and permanent rather than joint and interim. Given the lack of trust or empathy, there was little possibility for individuals and groups to assure each other that their realities were being seen and heard. Thus marked by polarized publics, the controversy wrought a solution that bred more distance and discord beneath an uneasy settlement. Yet the textbook case illuminates the potential for co-being as a praxis of the public. Perhaps the first step is disclosure, which Arendt describes as answering the question, "Who am I?": a question that cannot be answered only by describing one's talents and qualifications because, as she says, these can be hidden or displayed at will, while who-am-I? is "implicit in everything somebody says and does" (Arendt 1998 [1958], 179). Disclosure, in other words, is a form of truth-telling that is ingrained in the Gandhian understanding of Truth, the basis for ahimsa. Ahimsa, practice-able in all areas of life, will push against those positions that rest the story with "irreconcilable difference" and leave open the door for violence. In sum, an ethical investment in co-being is necessary to imagine and build a peaceful society that, at the end of the day, perhaps affirms an ancient truth: the recognition of difference is complete only when understanding of difference is procured through ahimsaic practices-how we share space, how we own things, and how we create the compassionate affect that leads to assurance.

\section{REFERENCES}

Arendt, Hannah 1998 [1958]

1968
The Human Condition. Chicago: University of Chicago Press.

Men in Dark Times. New York: Harcourt, Brace and World, Inc. 


\begin{tabular}{|c|c|}
\hline $\begin{array}{r}\text { Arnold, Matthew } \\
1865\end{array}$ & $\begin{array}{l}\text { "The Function of Criticism at the Present Time." } \\
\text { In Essays in Criticism, 1-41. London and } \\
\text { Cambridge: Macmillan \& Co. }\end{array}$ \\
\hline $\begin{array}{r}\text { Barba, Michael } \\
2016\end{array}$ & $\begin{array}{l}\text { "USF Professor Denounces Proposed } \\
\text { Elimination of 'India' from Textbooks." San } \\
\text { Francisco Examiner. March 25, 2016. Available } \\
\text { at http://www.sfexaminer.com/usf-professor-de } \\
\text { nounces-proposed-elimination-india-ca-text } \\
\text { books/. Accessed March 29, } 2016 .\end{array}$ \\
\hline $\begin{array}{r}\text { Benhabib, Seyla } \\
1993\end{array}$ & $\begin{array}{l}\text { "Feminist Theory and Hannah Arendt's Concept } \\
\text { of Public Space." History of Human Sciences } 6 \\
\text { (2): 97-114. }\end{array}$ \\
\hline $\begin{array}{r}\text { Butler, Judith } \\
2011\end{array}$ & $\begin{array}{l}\text { "Is Judaism Zionism?" In The Power of Religion } \\
\text { the Public Sphere, edited by Eduardo Mendieta } \\
\text { and Jonathan VanAntwerpen, 70-91. New York: } \\
\text { Columbia University Press. }\end{array}$ \\
\hline $\begin{array}{r}\text { CDE [California } \\
\text { Department of Education] } \\
1993\end{array}$ & $\begin{array}{l}\text { Available at http://www.cde.ca.gov/be/ag/ag/ } \\
\text { documents/hssnotice022706a1.pdf. Accessed } \\
\text { August 7, } 2015 .\end{array}$ \\
\hline $\begin{array}{r}\text { Concerned Historians } \\
2009\end{array}$ & $\begin{array}{l}\text { Available at http://www.concernedhistorians. } \\
\text { org/content_files/file/LE/187.pdf. Accessed } \\
\text { August 5, } 2015 \text {. }\end{array}$ \\
\hline $\begin{array}{r}\text { Cutler, Norman } \\
1987\end{array}$ & $\begin{array}{l}\text { Songs of Experience: The Poetics of Tamil } \\
\text { Devotion. Bloomington, IN: Indiana University } \\
\text { Press. }\end{array}$ \\
\hline $\begin{array}{r}\text { Derrida, Jacques } \\
2012\end{array}$ & $\begin{array}{l}\text { "Avowing-The Impossible: 'Returns,' } \\
\text { Repentance, and Reconciliation. A Lesson,” } \\
\text { translated by G. Anidjar. In Living Together: } \\
\text { Jacques Derrida's Communities of Violence and } \\
\text { Peace, edited by Elisabeth Weber, 18-41. New } \\
\text { York: Fordham University Press. }\end{array}$ \\
\hline Ettukudi Murugan & $\begin{array}{l}\text { Available at http://ettukudimuruguantemple. } \\
\text { com. }\end{array}$ \\
\hline $\begin{array}{r}\text { Fischer, Louis } \\
1942\end{array}$ & $\begin{array}{l}\text { A Week With Gandhi. New York: Duell, Sloan } \\
\text { and Pearce. }\end{array}$ \\
\hline $\begin{array}{r}\text { Gandhi, M. K. } \\
1921 \text { [1999] }\end{array}$ & $\begin{array}{l}\text { "Introspection." Young India. November 17. In } \\
\text { Collected Works of Mahatma Gandhi. 25th vol., } \\
\text { 121. New Delhi: Publications Division of } \\
\text { Government of India. }\end{array}$ \\
\hline
\end{tabular}


1931 [1999] "Speech at Meeting in Lausanne." December 8. Collected Works of Mahatma Gandhi. 54th vol., 270. New Delhi: Publications Division of Government of India.

1932 From Yeravda Mandir: Ashram Observances. Ahmedabad, India: Navajivan Publishing House.

1955 Ashram Observances in Action. Ahmedabad, India: Navajivan Publishing House.

1993 [1957] An Autobiography: The Story of My Experiments with Truth, translated by Mahadev H. Desai. Boston, MA: Beacon Press.

Guha, Ramachandra "766 Kilometers from Somewhere: Sevagram." 2004 In The Last Liberal and Other Essays, edited by Ramachandra Guha, 11-23. New Delhi, India: Permanent Black.

Hardy, Friedhelm

1979

Habermas, Jürgen 2011

Kailasam, Bala, Min Bimbangal, and Ganapati Sthapati 1990

Mehta, Ved 1993

Nandy, Ashis 1995

Narayanan, Vasudha 1987
"The Philosopher as Poet: A Study of Vedāntadeśika's Dehalīśastuti." Journal of Indian Philosophy 7: 277-325.

“"The Political': The Rational Meaning of a Questionable of Political Theology." In The Power of Religion the Public Sphere, edited by Eduardo Mendieta and Jonathan VanAntwerpen, 15-33. New York: Columbia University Press.

"Vāstu Mārabu: The Living Tradition, A Shilpi Speaks. A Film.” Mylapore, Madras, India: Min Bimbangal.

Mahatma Gandhi and His Apostles. New Haven, CT: Yale University Press.

"History's Forgotten Doubles." History and Theory 34 (2): 44-66.

The Way and the Goal: Expressions of Devotion in the Early Srivaisnava Tradition. Washington, D.C: Institute for Vaishnava Studies (American University) and Cambridge: Center for the Study of World Religions. 


\begin{tabular}{|c|c|}
\hline $\begin{array}{r}\text { Nandy, Ashis } \\
2009\end{array}$ & $\begin{array}{l}\text { "Open Pasts Open Futures." Available at http:// } \\
\text { almostisland.com/monsoon_2009/essay/pdfs/ } \\
\text { china.pdf. Accessed December 6, 2015. }\end{array}$ \\
\hline $\begin{array}{r}\text { Narayanan, Vasudha } \\
2007\end{array}$ & $\begin{array}{l}\text { "Weaving Garlands in Tamil: The Poetry of the } \\
\text { Âlvār." In Krishna: A Sourcebook, edited by } \\
\text { Edwin Bryant, 187-204. New York: Oxford } \\
\text { University Press. }\end{array}$ \\
\hline $\begin{array}{r}\text { Parekh, Bhikhu C. } \\
1989\end{array}$ & $\begin{array}{l}\text { Gandhi's Political Philosophy: A Critical } \\
\text { Examination. Notre Dame, IN: University of } \\
\text { Notre Dame Press. }\end{array}$ \\
\hline $\begin{array}{r}\text { Prasad, Leela } \\
2007\end{array}$ & $\begin{array}{l}\text { Poetics of Conduct: Oral Narrative and Moral } \\
\text { Being in a South Indian Town. New York: } \\
\text { Columbia University Press. }\end{array}$ \\
\hline 2015 & $\begin{array}{l}\text { “Cordelia’s Salt: Interspatial Reading of Indic } \\
\text { Filial-Love Stories." Oral Tradition } 29 \text { (2): } \\
245-70 .\end{array}$ \\
\hline $\begin{array}{r}\text { Rudolph, Susanne, } \\
\text { and Lloyd Rudolph } \\
2006\end{array}$ & $\begin{array}{l}\text { "The Coffee Shop and the Ashram Revisited: } \\
\text { How Gandhi Democratized Habermas' Public } \\
\text { Sphere." In Postmodern Gandhi and Other } \\
\text { Essays, edited by Susanne Rudolph and Lloyd } \\
\text { Rudolph, 140-74. Chicago: University of } \\
\text { Chicago Press. }\end{array}$ \\
\hline $\begin{array}{r}\text { Sarkar, Tanika } \\
2011\end{array}$ & $\begin{array}{l}\text { "Gandhi and Social Relations." In The } \\
\text { Cambridge Companion to Gandhi, edited by } \\
\text { Judith M. Brown and Anthony Parel, 135-54. } \\
\text { New York: Cambridge University Press. }\end{array}$ \\
\hline $\begin{array}{r}\text { Serrano, Andres } \\
1997\end{array}$ & $\begin{array}{l}\text { "Idiosyncratic Iconography." In The } \\
\text { Photographic Paradigm, Lier en Boog Series of } \\
\text { Philosophy and Art Theory 12, edited by } \\
\text { Annette W. Balkema and Henk Slager, 106-9. } \\
\text { Atlanta and Amsterdam: Editions Rodopi B.V. }\end{array}$ \\
\hline $\begin{array}{r}\text { Skaria, Ajay } \\
2002\end{array}$ & $\begin{array}{l}\text { "Gandhi's Politics: Liberalism and the Question } \\
\text { of the Ashram." The South Atlantic Quarterly } \\
101 \text { (4): 955-86. }\end{array}$ \\
\hline $\begin{array}{r}\text { Suhrud, Tridip } \\
2011\end{array}$ & $\begin{array}{l}\text { "Gandhi's Key Writings: In Search of Unity." In } \\
\text { The Cambridge Companion to Gandhi, edited by } \\
\text { Judith M. Brown and Anthony Parel, 71-92. } \\
\text { New York: Cambridge University Press. }\end{array}$ \\
\hline
\end{tabular}


Thompson, Mark 1993

Venkatesan, Archana

2011

Vinayak, Bharne and Krupali Krusche

2012

Warner, Michael

2005

Weber, Thomas

2011
Gandhi and His Ashrams. Mumbai, India: Popular Prakashan.

"Ālvār." In Oxford Bibliographies in Hinduism. Available at http://www.oxfordbibliographies. com/view/document/obo-9780195399318/obo9780195399318-0063.xml. Accessed August 4, 2015.

Rediscovering the Hindu Temple: The Sacred Architecture and Urbanism of India. Newcastle, UK: Cambridge Scholars.

Publics and Counterpublics. New York: Zone Books.

"Gandhi's Moral Economics: The Sins of Wealth without Work and Commerce without Morality." In The Cambridge Companion to Gandhi, edited by Judith M. Brown and Anthony Parel, 135-54. New York: Cambridge University Press. 